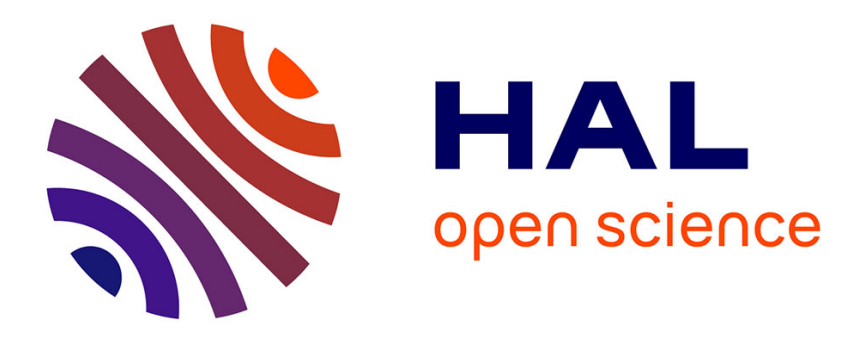

\title{
Tracing disinfection byproducts in full-scale desalination plants
}

Julien Le Roux, Nabil Nada, Muhammad Tariq Khan, Jean-Philippe Croué

\section{To cite this version:}

Julien Le Roux, Nabil Nada, Muhammad Tariq Khan, Jean-Philippe Croué. Tracing disinfection byproducts in full-scale desalination plants. Desalination, 2015, 359, 10.1016/j.desal.2014.12.035 . hal-01211480

\section{HAL Id: hal-01211480 \\ https://hal-enpc.archives-ouvertes.fr/hal-01211480}

Submitted on 7 Oct 2015

HAL is a multi-disciplinary open access archive for the deposit and dissemination of scientific research documents, whether they are published or not. The documents may come from teaching and research institutions in France or abroad, or from public or private research centers.
L'archive ouverte pluridisciplinaire HAL, est destinée au dépôt et à la diffusion de documents scientifiques de niveau recherche, publiés ou non, émanant des établissements d'enseignement et de recherche français ou étrangers, des laboratoires publics ou privés. 


\title{
Tracing Disinfection Byproducts in Full-Scale
}

\section{Desalination Plants}

\author{
Julien Le Roux ${ }^{1}$, Nabil Nada ${ }^{2}$, Muhammad Tariq Khan ${ }^{1}$, Jean-Philippe Croué ${ }^{1 *}$ \\ ${ }^{1}$ Water Desalination and Reuse Center, 4700 KAUST, Thuwal 23955-6900, Saudi Arabia. \\ ${ }^{2}$ NOMAC, P.O. Box 8337, Jeddah 21482, Saudi Arabia
}

E-mail addresses: julien.leroux5@gmail.com (Julien Le Roux),jp.croue@kaust.edu.sa (Jean-Philippe

Croué), muhammed.khan@kaust.edu.sa (Muhammad Tariq Khan),n.nada@nomac.com (Nabil Nada)

* Corresponding author present address: Curtin Water Quality Research Centre, Curtin University, Perth Western Australia 6845, Australia; phone: +61 89266 9793; Mobile: 0438860 666; email: jeanphilippe.croue@curtin.edu.au

\begin{abstract}
The aim of this study was to assess the formation and the behavior of halogenated byproducts (regulated THMs and HAAs, as well as nitrogenous, brominated and iodinated DBPs including the emerging iodoTHMs) along the treatment train of full-scale desalination plants. One thermal multi-stage flash distillation (MSF) plant and two reverse osmosis (RO) plants located on the Red Sea coast of Saudi Arabia. DBPs formed during the prechlorination step were efficiently removed along the treatment processes (MSF or RO). Desalination plants fed with good seawater quality and using intermittent chlorine injection did not show high DBP formation and discharge. One RO plant with a lower raw water quality and using continuous chlorination at the intake formed more DBPs. In this plant, some non-regulated DBPs (e.g., dibromoacetonitrile and iodo-THMs) reached the product water in low concentrations $(<1.5 \mu \mathrm{g} / \mathrm{L})$. Regulated THMs and HAAs were far below their maximum contamination
\end{abstract}


levels set by the US Environmental Protection Agency. Substantial amounts of DBPs are disposed to the sea, low concentrations of DBPs were indeed detected in the water on shore of the desalination plants.

\section{Keywords}

Chlorination, desalination plants, disinfection byproducts, haloacetic acids, haloacetonitriles, multistage flash distillation, reverse osmosis, trihalomethanes, iodinated DBPs.

\section{Introduction}

Chlorine is widely used as an inexpensive and effective biocide for drinking water disinfection. Prechlorination is commonly used to control biofouling in seawater desalination plants (e.g., thermal multi-stage flash distillation - MSF - or seawater reverse osmosis - SWRO). Large amounts of disinfectant can be required to maintain a residual during algal bloom events. As a result of the reaction with marine organic matter, a large diversity of disinfection byproducts (DBPs) is formed during seawater chlorination, including the regulated trihalomethanes (THMs) and haloacetic acids (HAAs). Nitrogenous DBPs (N-DBPs) generally form in much smaller amounts than regulated DBPs, but have been a growing concern over the past decade because of their higher health risk [1,2]. In vitro mammalian cell tests demonstrated that haloacetonitriles (HANs), halonitromethanes (HNMs) and haloacetamides (HAcAms) are more cytotoxic and genotoxic (up to 2 orders of magnitude) than nonnitrogenous THMs and HAAs [3]. N-DBPs formation has been associated with the presence of nitrogen-containing compounds (e.g., ammonia, dissolved organic nitrogen such as amino acids) in waters impacted by wastewater or algal organic matter (AOM) [4,5]. Moreover, the presence of high concentrations of bromide and iodide ions in seawater (i.e., $60 \mathrm{mg} \mathrm{Br} / \mathrm{L}$ and $0.05 \mathrm{mg} \mathrm{I} / \mathrm{L}$ in the Red Sea, respectively) promotes the formation of brominated and iodinated byproducts (Br-DBPs and IDBPs) that are often more toxic than their chlorinated analogs $[3,6,7]$. Due to the toxicity and carcinogenicity of DBPs, Maximum Contaminant Levels (MCLs) have been set by the US 
Environmental Protection Agency (US EPA) for total THMs $(80 \mu \mathrm{g} / \mathrm{L})$, total HAAs $(60 \mu \mathrm{g} / \mathrm{L})$ and bromate $(10 \mu \mathrm{g} / \mathrm{L})[8]$, and are enforced by the Saudi Arabian Standards Organization.

Studies on the impact of brine discharges from desalination plants focused mainly on salinity, scaling control additives and the presence of heavy metals such as copper released from corrosion in multi-stage flash plants $[9,10]$. Limited data regarding the discharge of DBPs has been published and little is known about their potential impact on aquatic organisms. THMs have been detected near distillation plants at levels of up to $9.5 \mu \mathrm{g} / \mathrm{L}$ [11] and $90 \mu \mathrm{g} / \mathrm{L}$ [12]. Bromoform and dibromoacetonitrile (DBAN) concentrations were reported in cooling water discharges of European coastal power plants (0.72-29.2 $\mu \mathrm{g} / \mathrm{L}$ and $0.1-3.15 \mu \mathrm{g} / \mathrm{L}$, respectively) [13]. Although these concentrations are supposed to be reduced by mixing coupled with biotic (e.g., biodegradation) and abiotic mechanisms (e.g., evaporation, photolysis) within a few kilometers [14], they could have an impact in the vicinity of the point of discharge, especially towards sensitive species exposed to chronic concentrations. THMs and HAAs were found to affect bivalves and aquatic macrophytes $[15,16]$. A median lethal dose of $1000 \mu \mathrm{g} / \mathrm{L}$ was reported for bromoform exposure to oyster (Crassostrea virginica) larvae and significant toxicity was observed at concentrations as low as $50 \mu \mathrm{g} / \mathrm{L}$ [15]. Very low concentrations of monochloroacetic acid (MCAA) and monobromoacetic acid (MBAA) $(7 \mu \mathrm{g} / \mathrm{L}$ and $20 \mu \mathrm{g} / \mathrm{L}$, respectively) were found to inhibit growth in green algae Scenedesmus subspicatus [16]. However, no information is available about the occurrence of other DBPs (N-DBPs, I-DBPs) and their impact on marine organisms.

Very few studies reported the occurrence of DBPs in full-scale seawater desalination plants, and these studies mainly focused on THMs [17-19]. THMs concentrations in the range $2.7-22.8 \mu \mathrm{g} / \mathrm{L}$ were found in the distillate of MSF plants in Kuwait [18]. Very low levels of HAAs were reported in the product water of a MSF plant in Saudi Arabia (1.5-2.4 $\mu \mathrm{g} / \mathrm{L})$ [20]. In MSF plants, more than 98\% of THMs formed after chlorination are transferred to the atmosphere through the venting system. In SWRO plants, the apparent rejection of DBPs depends on the nature of the compounds (e.g., molecular weight, width, charge and hydrophobicity), as well as the membrane properties (e.g., molecular weight cut-off, 
surface charge and hydrophobicity) and feed water composition (e.g., pH, temperature, DOC, inorganic compounds) [21,22]. A few studies reported the rejection of DBPs by RO or nanofiltration membranes in lab-scale experiments or pilot plants [23-25]. The rejection of negatively charged HAAs (average rejections $86 \%-94 \%$ ) by RO membranes is higher than that of neutral byproducts (average rejections $\sim 60 \%-90 \%$ ) $[23,25]$. Among neutral byproducts, the lowest rejection was observed for chloroform (TCM) ( 60\%), because of its low molecular weight $(119.4 \mathrm{~g} / \mathrm{mol})$ [25]. While these values have been reported in lab-scale or pilot-scale studies, data on DBP occurrence and rejection in full-scale SWRO desalination plants is lacking, especially with respect to emerging species such as N-DBPs or iodoTHMs.

The goal of this study was to assess the formation and the behavior of various halogenated byproducts (THMs, HAAs, HANs) along the treatment train of different full-scale desalination plants, to evaluate the removal of DBPs by desalination processes and to monitor the quality of the water produced as well as the brine. The occurrence of DBPs was analyzed in one thermal MSF plant and two SWRO plants equipped with Polyamide (PA) and Cellulose Triacetate (CTA) membranes, all located on the Red Sea

coast of Saudi Arabia. In order to better understand the role of foulant material on the production of DBPs in the CTA RO train that is fed with chlorinated water, chlorination of the material accumulated at the surface of the membrane (i.e., recovered from harvested RO module) was performed in batch mode.

\section{Materials and Methods}

\subsection{Materials}

All reagents were of commercial grade and were used without further purification. MilliQ water was produced with a Millipore system. Sodium hypochlorite $(\mathrm{NaOCl}, 5.65-6 \%$, Fisher Scientific) was used for DBP formation potential tests. Sodium thiosulfate (Fisher Scientific) was used to quench residual 
chlorine. THM calibration mix (THM4: chloroform (TCM), dichlorobromomethane (DCBM), dibromochloromethane (DBCM) and bromoform (TBM)), a mixed standard containing haloacetonitriles (HANs), trichloronitromethane (TCNM, or chloropicrin) and haloketones (HKs) (EPA 551B Halogenated Volatiles Mix), a mixed standard containing 9 HAAs (EPA 552.2 Methyl Ester Calibration Mix), iodoform and surrogate standard decafluorobiphenyl were supplied from Supelco (SigmaAldrich). Iodo-trihalomethanes (I-THMs) (dichloroiodomethane $\left(\mathrm{CHCl}_{2} \mathrm{I}\right)$, chlorodiiodomethane $\left(\mathrm{CHClI}_{2}\right)$, chlorobromoiodomethane $(\mathrm{CHBrClI})$, dibromoiodomethane $\left(\mathrm{CHBr}_{2} \mathrm{I}\right)$, bromodiiodomethane $\left.\left(\mathrm{CHBrI}_{2}\right)\right)$ were purchased from Cansyn Chem. Corp. Synthetic seawater was prepared following the protocol of Grasshoff et al [26] with inorganic (no organic matter added) composition similar to that of the raw seawater at SWRO plant 2 (i.e., same alkalinity, $60 \mathrm{mg} \mathrm{Br} / \mathrm{L}, 0.05 \mathrm{mg} \mathrm{I} / \mathrm{L}, \mathrm{pH} 8.2$ ).

\subsection{Sampling}

All samples from the desalination plants were collected in $500 \mathrm{~mL}$ amber bottles before and after each treatment step, and filled without headspace to avoid the volatilization of DBPs. Residual chlorine was quenched immediately in slight excess of sodium thiosulfate and transported in coolers with icepacks and after few hours of transportation stored at $4^{\circ} \mathrm{C}$ before analyses. All bottles were washed with MilliQ water and baked at $500^{\circ} \mathrm{C}$ for at least $5 \mathrm{~h}$ prior to use. At the MSF plant, samples were collected in July 2012 along one evaporator unit: raw seawater, chlorinated seawater, feed after heat rejection, brine recycle, brine blowdown, and distillate, as shown in Figure S1 (Supporting Information, SI). The design capacity of the MSF unit was $74,000 \mathrm{~m}^{3} / \mathrm{d}$, with recirculating brine consisting of 21 stages (19 heat recovery stages and 2 heat rejection stages). A chlorine residual of $0.25 \mathrm{mg} / \mathrm{L}$ as $\mathrm{Cl}_{2}$ was maintained continuously to the inlet of the heat rejection section. SWRO plant 1 was located in the same area as the MSF plant, and samples were collected in July 2012 from: raw seawater, chlorinated seawater, after dual media filters (DMF), after micron cartridge filters (MCF) and sodium bisulfite (SBS), $1^{\text {st }}$ pass permeate, $2^{\text {nd }}$ pass permeate, $1^{\text {st }}$ pass brine, and $2^{\text {nd }}$ pass brine (Figure S2, SI). SWRO plant 1 was 
equipped with polyamide (PA) RO membrane and its design capacity is $150,000 \mathrm{~m}^{3} / \mathrm{d}(10$ trains). A chlorine residual of $0.50 \mathrm{mg} / \mathrm{L}$ as $\mathrm{Cl}_{2}$ (measured between DMF and MCF) was maintained at the time of sampling, and was usually applied once a week for three hours in normal operating conditions. Residual chlorine is quenched using SBS immediately prior the $1^{\text {st }}$ pass RO filtration. SWRO plant 2 had a design capacity of $216,000 \mathrm{~m}^{3} / \mathrm{d}$ water production with two passes of RO filtration. Continuous chlorination (0.7-1 mg/L) was applied at the intake point. The first pass of RO filtration consisted of cellulose triacetate (CTA) membranes, used for their resistance to chlorine. SBS was normally applied before this first pass of RO and was stopped for $1 \mathrm{~h}$ every $8 \mathrm{~h}$ to limit the biofouling of the membrane. Two sampling campaigns (May and July 2013) were performed at SWRO plant 2. Duplicate samples were collected at similar locations than SWRO plant 1 , with additional samples at the $2^{\text {nd }}$ pass RO step comprising two stages and product water after potabilization (i.e., remineralization) (Figure S3, SI). During the first sampling campaign (May 2013), samples at the $1^{\text {st }}$ pass RO (permeate and concentrate) were collected during normal dechlorination conditions $(1.5-2.5 \mathrm{mg} / \mathrm{L}$ of SBS $)$ and during the chlorination period. Raw seawater quality parameters (i.e., pH, turbidity, DOC, TDS, chloride, bromide and iodide ions) for each plant are described in Table S1 of the SI.

\subsection{Isolation and cleaning of RO membrane deposits}

Deposits from the fibers of a RO module from SWRO plant 2 were subjected to several steps of isolation and cleaning. First, fibers were harvested from the module, rinsed with Milli-Q water and the foulant material was recovered using sonication in Milli-Q water. The sample was dialyzed against oxalic acid (1\% weight/volume, to remove iron) or oxalic acid followed by hydrofluoric acid (1\% weight/volume, to remove silicate). After a final dialysis against Milli-Q water, powdered foulant materials (no purification, iron-free, iron and silicate-free) were recovered after freeze-drying.

\subsection{DBP formation potential}

Chlorination experiments of membrane deposits were performed in $500 \mathrm{~mL}$ sealed amber bottles. All 
glassware used for these experiments was washed with Milli-Q water and baked at $500^{\circ} \mathrm{C}$ during at least $5 \mathrm{~h}$ prior to use. Colloidal suspensions of the membrane foulant $(1 \mathrm{mg} \mathrm{C} / \mathrm{L})$ were prepared in synthetic seawater $(\mathrm{pH} 8.3)$ under sonication and chlorinated for $24 \mathrm{~h}$, following the approach of Krasner et al. [27], using a chlorine dosage calculated by Equation 1.

$\mathrm{Cl}_{2}$ dose $(\mathrm{mg} / \mathrm{L})=3$ DOC $(\mathrm{mg} \mathrm{C} / \mathrm{L})+7.6 \mathrm{NH}_{3}(\mathrm{mg} \mathrm{N} / \mathrm{L})+10(\mathrm{mg} / \mathrm{L})$

At the end of the reaction time, chlorine residual was quenched using a slight excess of sodium thiosulfate.

\subsection{Analyses}

Nine THMs (4 chlorinated and brominated THMs (THM4) and 5 I-THMs), four haloacetonitriles (HAN4), two haloketones (HKs), and chloropicrin were extracted and analyzed following EPA method 551, which consists of a liquid-liquid extraction using MTBE followed by gas chromatography coupled with electron capture detector (GC/ECD) [28]. Nine HAAs (HAA9) were extracted and analyzed following EPA method 552.2, which is based on a liquid-liquid extraction in acidic conditions followed by derivatization to methyl esters using acidic methanol and analysis by gas chromatography coupled

with mass spectrometry (GC/MS) [29]. All DBPs analyzed are described in Table S2 (SI). Method detection limits for HANs, HKs, TCNM, $\mathrm{Cl}$ and Br-THMs, HAAs and I-THMs were $0.13 \mu \mathrm{g} / \mathrm{L}, 0.08$ $\mu \mathrm{g} / \mathrm{L}, 0.12 \mu \mathrm{g} / \mathrm{L}, 0.02 \mu \mathrm{g} / \mathrm{L}, 0.02 \mu \mathrm{g} / \mathrm{L}$ and $0.09 \mu \mathrm{g} / \mathrm{L}$ respectively, based on standard deviation of 3 replicates. Dissolved organic carbon (DOC) content was measured by a Shimadzu TOC-Vcsh Analyzer. Analytical details of LC-OCD analyses are provided in Text S1 of the SI.

\section{Results and discussion}

\subsection{DBP results in $M S F$ plant}

Because of the presence of high bromide ion content in the seawater, the proportion of brominated 
DBPs formed after chlorination was more important than the amount of chlorinated DBPs. This is explained by the fast reaction between chlorine and bromide ion leading to the production of hypobromous acid (HOBr) (Equation 2), which is a more reactive oxidizing species than hypochlorous acid $(\mathrm{HOCl})$ [30]. Depending on $\mathrm{pH}$, hypobromite ion can also be present $(\mathrm{pKa}=8.8)$ (Equation 3).

$$
\begin{aligned}
& \mathrm{HOCl}+\mathrm{Br}^{-} \rightarrow \mathrm{HOBr}+\mathrm{Cl}^{-} \\
& \mathrm{HOBr} \leftrightarrows \mathrm{OBr}^{-}+\mathrm{H}^{+}
\end{aligned}
$$

The speciation of halogenated DBPs is affected by the ratio between $\mathrm{HOBr}$ (and thus the initial concentration of bromide in seawater) and DBP precursors (i.e., dissolved organic carbon). Because of the high concentration of bromide ion $\left(60 \mathrm{mg} \mathrm{Br}^{-} / \mathrm{L}\right)$ in the seawater, bromoform (TBM) was the dominant species observed in the chlorinated seawater $(6.10 \mu \mathrm{g} / \mathrm{L}$ in $\mathrm{CSW})$, accounting for $95 \%$ of THM4. No chloroform was detected at any step of the two desalination plants (Table S3, SI). Similarly, dibromoacetonitrile (DBAN) and dibromoacetic acid (DBAA) were the dominant species among the HANs and HAAs (0.76 and $2.05 \mu \mathrm{g} / \mathrm{L}$, respectively). Neither the two monitored haloketones nor chloropicrin were detected in any samples. This is explained by the high concentrations of bromide ion, probably favoring the formation of brominated analogs of these compounds (e.g. dibromopropanone, bromopicrin), which were not monitored in this study due to the lack of standards.

An unexpected trace amount of TBM $(0.29 \mu \mathrm{g} / \mathrm{L})$ was detected in the raw seawater, as described in section 3.5. (Figure 5). A large amount of TBM was observed in the feed water of the MSF plant after heat rejection $(45.51 \mu \mathrm{g} / \mathrm{L}$, Table S3, SI), following the $1.5 \mathrm{~min}$ chlorination reaction time, while the TBM content was only $6.10 \mu \mathrm{g} / \mathrm{L}$ just after the point of chlorine injection (i.e., fast reaction occurring before quenching residual chlorine). Similarly, HAN4 and HAA9 concentrations increased in the feed water (4.87 and $5.95 \mu \mathrm{g} / \mathrm{L}$, respectively) (Figure 1a). While they were present in low amounts in the chlorinated seawater sample $(<0.5 \mu \mathrm{g} / \mathrm{L})$, MCAA, DCAA and TCAA were not detected in the feed water. All halogenated DBPs were extensively removed after distillation. The large removal of all volatile DBPs occurs through the venting system of the MSF unit, because of the full vacuum used as 
well as the high temperature reached in the first stage of the unit $\left(110^{\circ} \mathrm{C}\right)$. However, some DBPs present in the gaseous form in the flash chamber can condense along with water vapor. Small amounts of brominated THMs were still detected in the distillate of the MSF plant (THM4 $<0.4 \mu \mathrm{g} / \mathrm{L}$, accounting for $4 \%$ of the THM 4 concentration in the brine recycle). Only $5.6 \%$ of the THM 4 present in brine recycle were retained in the brine rejected as blowdown $(0.53 \mu \mathrm{g} / \mathrm{L})$, thus $90 \%$ of THM4 were rejected as vent gases. THM4 concentration in the recycled brine was much lower than in the make-up feed water before deaeration ( 9.53 and $47 \mu \mathrm{g} / \mathrm{L}$, respectively). This is attributed to the dilution effect (by a factor of 3.3) when mixing make-up water with the brine in the last stage, and also to partial removal in the deaeration unit [17]. DBAN was also detected in the distillate at concentrations of up to $0.45 \mu \mathrm{g} / \mathrm{L}$, accounting for $31 \%$ of the brine concentration, and $0.53 \mu \mathrm{g} / \mathrm{L}$ were discharged in the brine blowdown. No other DBPs (e.g., HAAs) were detected in the distillate. HAA9 concentration in the brine blowdown was $4.50 \mu \mathrm{g} / \mathrm{L}(82 \%$ of the HAA9 concentration analyzed in the brine recycle), indicating a low elimination through the venting system $(18 \%)$. This is due to the lower volatility of HAAs as compared to THMs. Overall, the elimination of THM4 and HAN4 from the make-up feed to the distillate was 99.2\% and 90.7\%, respectively. The removal of THM4 was higher than previous observations made in similar MSF plants (89-94\% removal) $[17,18]$.

The concentrations detected in the distillate were significantly lower than the recommendations of the World Health Organization (WHO) for these DBPs $(100 \mu \mathrm{g} / \mathrm{L}$ for TBM and $70 \mu \mathrm{g} / \mathrm{L}$ for DBAN) [31]. THM4 and HAA9 were also far below the Maximum Contaminant Levels (MCL) set by the US Environmental Protection Agency (USEPA) and followed in Saudi Arabia (80 $\mu \mathrm{g} / \mathrm{L}$ for THM4 and 60 $\mu \mathrm{g} / \mathrm{L}$ for HAA9) [8]. 


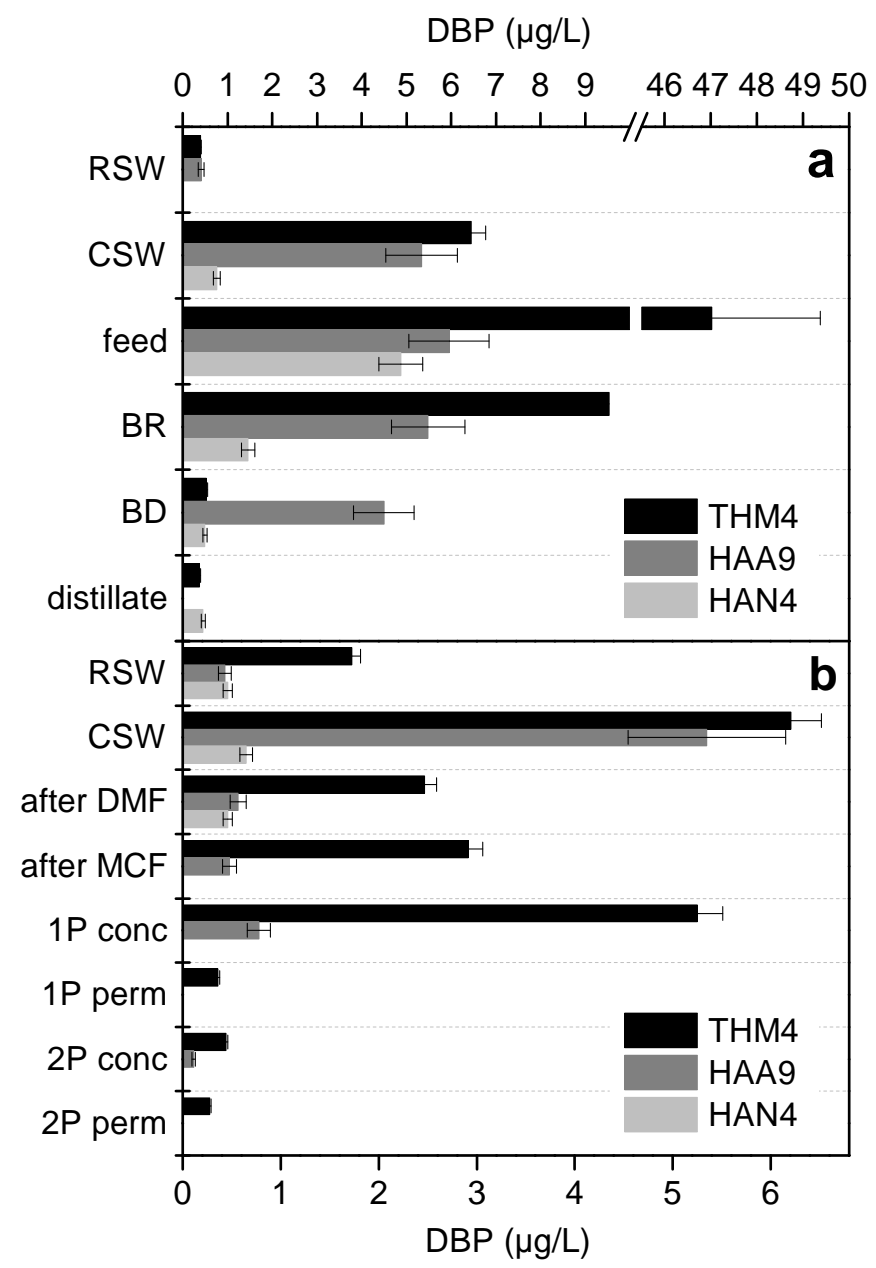

Figure 1. Concentrations of THM4, HAA9 and HAN4 in (a) MSF plant and (b) SWRO plant 1. RSW: raw seawater, CSW: chlorinated seawater, BR: brine recycle, BD: brine blowdown, DMF: dual media filters, MCF: micron cartridge filters, $1 \mathrm{P} / 2 \mathrm{P}: 1^{\text {st }}$ and $2^{\text {nd }} \mathrm{RO}$ pass, conc: concentrate, perm: permeate. Error bars represent the standard deviation between duplicate measurements.

\subsection{DBP results in $S W R O$ plant 1}

In SWRO plant 1, TBM was the major DBP quantified in the sample collected just after the chlorination point, i.e., $5.93 \mu \mathrm{g} / \mathrm{L}$ in CSW (Table S4, SI). Similarly to the MSF plant, DBAN and DBAA were the dominant HANs and HAAs species, respectively. No other HANs were detected, while small amounts of other HAA species were present in the chlorinated seawater sample (i.e., MCAA, 
MBAA, DCAA and TBAA, see Table S4, SI). TBM content was slightly reduced after the dual media filters $(\mathrm{DMF})$. In the presence of residual oxidant, this can be attributed to both the reduction of organic DBP precursors by the DMF, and to the adsorption of DBPs on the DMF materials. Because of the RO membrane rejection properties, the amount of halogenated DBPs was higher (i.e., concentration effect) in the RO $1^{\text {st }}$ pass concentrate as compared to the feed water after MCF and SBS (e.g., $4.96 \mu \mathrm{g} / \mathrm{L}$ and $2.68 \mu \mathrm{g} / \mathrm{L}$ of TBM, respectively) (Figure $1 \mathrm{~b})$. Small amounts of THMs $(0.17 \mu \mathrm{g} / \mathrm{L}$ of TBM and 0.10 $\mu \mathrm{g} / \mathrm{L}$ of $\mathrm{DBCM}$ ) were still detected in the permeate of the $2^{\text {nd }}$ pass of the RO plant. No other DBPs were detected in the permeate. It is important to remember that residual oxidant was quenched prior to RO filtration to avoid the degradation of the PA layer. The overall removal of THM4 between the chlorination step and the final permeate was 95.6\%. This rejection of THM4 is in agreement with results obtained in lab-scale studies for TBM (i.e., 90\% rejection)[25]. All HANs and HAAs were totally removed by the RO membranes. This is also consistent with lab-scale observations from the literature, where the negatively charged HAAs were rejected more effectively (i.e., $86-94 \%$ rejection for all HAAs) than neutral DBPs by composite polyamide RO membranes [25]. Because the MSF plant and SWRO plant 1 are both located in the same area exhibiting a relatively low DOC $(0.98 \mathrm{mg}$ C/L, Table $\mathrm{S} 1, \mathrm{SI})$, the overall DBP production was quite low. Concentrations of halogenated DBPs detected in the permeate of the RO plant were also significantly lower than the recommendations of WHO and the MCLs set by the USEPA described above.

\subsection{DBP results in SWRO plant 2}

Two sampling campaigns were performed at the SWRO plant 2 in May and July 2013. The raw seawater was more enriched in dissolved organics $(\mathrm{DOC}=1.62$ and $1.33 \mathrm{mg} \mathrm{C} / \mathrm{L}$ in May and July 2013, respectively) as compared to $\mathrm{SWRO}$ plant $1(\mathrm{DOC}=0.98 \mathrm{mg} \mathrm{C} / \mathrm{L})$. The higher DOC content, mainly represented by a more abundant biopolymers content (indicator of stronger biological activity, see Figure S4, SI), as well as the continuous chlorination condition, would probably explain the higher DBP 
formation observed after chlorination at SWRO plant 2 (Figure 2, Table S5 and Table S6, SI). THMs and HAAs followed the same trends between the two sampling campaigns, concentrations being slightly lower in July than in May due to the lower DOC content (Figure 2). This lower concentration in July could also be due to the slightly higher temperature of seawater in July $\left(31-32^{\circ} \mathrm{C}\right)$ as compared to May $\left(29^{\circ} \mathrm{C}\right)$. THM4 concentrations $(14.5-18.4 \mu \mathrm{g} / \mathrm{L})$ in the chlorinated seawater were $2-3$ times higher than in SWRO plant 1, while HAA9 $(5.7-6.9 \mu \mathrm{g} / \mathrm{L})$ were similar. HANs concentrations in the chlorinated seawater collected before DMF (0.43-0.72 $\mu \mathrm{g} / \mathrm{L})$ were also comparable to those in SWRO plant 1, but the concentrations observed in the following steps were considerably higher (e.g., 2.34-4.20 $\mu \mathrm{g} / \mathrm{L}$ after DMF). HANs concentrations were also significantly higher in May than in July. The lower raw seawater quality observed in SWRO plant 2, especially in May, can probably be associated with the presence of higher levels of organic nitrogen in the raw seawater. Raw seawater with strong biological activity, e.g., algal bloom events, which occur frequently in shallow coastal Red Sea and the Persian Gulf areas, incorporates higher nitrogenous moieties responsible for higher formation of N-DBPs. Moreover, organic nitrogen precursors are known to react slowly with chlorine to form HANs as compared to other DBPs [32], which would explain the higher concentrations observed after DMF (i.e., after longer contact times with chlorine). 


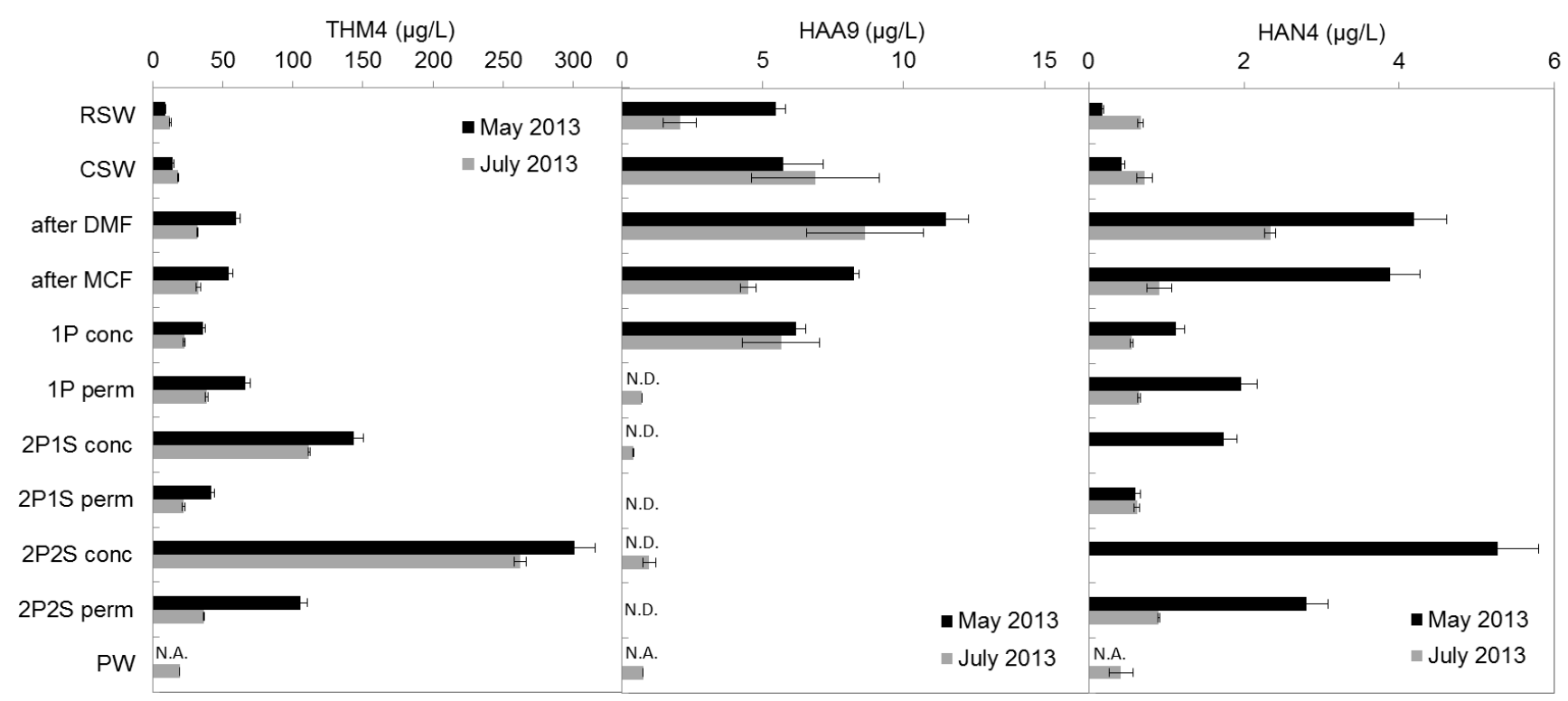

Figure 2. Concentrations of THM4, HAA9 and HAN4 in SWRO plant 2. RSW: raw seawater, CSW: chlorinated seawater, DMF: dual media filters, MCF: micron cartridge filters, $1 \mathrm{P} / 2 \mathrm{P}: 1^{\text {st }}$ and $2^{\text {nd }} \mathrm{RO}$ pass, $1 \mathrm{~S} / 2 \mathrm{~S}$ : $1^{\text {st }}$ and $2^{\text {nd }} \mathrm{RO}$ stage, perm: permeate, conc: concentrate, $\mathrm{PW}$ : product water. Error bars represent the standard deviation between duplicate samples. N.D.: Not Detected. N.A.: Not Applicable.

Opposite to SWRO plant 1, all DBPs concentrations (excluding the concentrates) reached a maximum after the DMF followed by a small decrease after MCF. The permeate of $1^{\text {st }}$ pass feeds the $1^{\text {st }}$ stage of a $2^{\text {nd }}$ pass; the concentrate of the $1^{\text {st }}$ stage enters the $2^{\text {nd }}$ stage of $2^{\text {nd }}$ pass RO filtration (Figure S3, SI). Hence brines are more and more concentrated along the passes and stages, which explains the important THMs and HANs concentrations observed in the concentrate of $2^{\text {nd }}$ pass $2^{\text {nd }}$ stage, $281.68 \pm 27.30 \mu \mathrm{g} / \mathrm{L}$ and $5.27 \pm 0.50 \mu \mathrm{g} / \mathrm{L}$, respectively.

The THM4 rejection after the $2^{\text {nd }}$ pass $/ 1^{\text {st }}$ stage (i.e., determined from the permeate going to the potabilization tank) was significantly lower (23-33\%) than in SWRO plant 1. During the two sampling campaigns, THMs and HANs concentrations at the first RO pass were even higher in the permeate $(52.38 \pm 19.56 \mu \mathrm{g} / \mathrm{L}$ and $1.31 \pm 0.93$, respectively $)$ than in the concentrate $(29.21 \pm 9.40 \mu \mathrm{g} / \mathrm{L}$ and $0.84 \pm$ 
0.40, respectively)(Figure 2). While HANs were totally removed in SWRO plant 1, their rejection in SWRO plant 2 varied from $84 \%$ in May to $32 \%$ in July, because of the important difference in the HANs concentrations of the RO feed water between the two sampling periods. TBM and DBAN concentrations in the product water were $19.05 \mu \mathrm{g} / \mathrm{L}$ and $0.42 \mu \mathrm{g} / \mathrm{L}$, respectively (Table S6, SI). The lower rejection of THMs and HANs in SWRO plant 2 as compared to SWRO plant 1 can be related to the use of cellulose triacetate (CTA) hollow fiber membranes, which are known to exhibit lower rejection of organic compounds, especially low molecular weight compounds such as THMs, as compared to polyamide RO membranes $[33,34]$. THMs rejections ranging from 1 to $30 \%$ were reported from a lab-scale study using CTA membranes and were attributed to the high affinity of the solutes to the membrane surface [34]. As observed in the SWRO plant 1, HAAs were substantially removed by the $1^{\text {st }}$ RO pass. No HAAs were detected in the samples following the $1^{\text {st }}$ RO pass during the $1^{\text {st }}$ sampling campaign (May 2013). However, the rejection was slightly lower during the second sampling campaign (July 2013), since $0.71 \mu \mathrm{g} / \mathrm{L}$ of DBAA was still present in the permeate of the $1^{\text {st }}$ pass ( $84 \%$ rejection). Even if no DBAA was detected in the permeate of the $2^{\text {nd }}$ pass $/ 1^{\text {st }}$ stage, small amounts $(0.76 \mu \mathrm{g} / \mathrm{L})$ were still present in the product water, due to potential reformation after the final chlorination step. THMs and HAAs were however significantly below the MCLs set by the USEPA. Based on the operational conditions of the different treatment units (i.e., water flow), mass flow rates were calculated for the major DBPs (TBM, DBAA and DBAN) in each plant and tentative mass balances were established (Table S8, SI). The plants presented rejects and recirculation loops making it difficult to calculate accurate mass balances for all steps, but TBM mass balance was generally consistent in $1^{\text {st }}$ pass and $2^{\text {nd }}$ pass of SWRO plants. In some cases (e.g., DBAA in $1^{\text {st }}$ pass of SWRO plant 1 and SWRO plant 2), the mass balance was not verified. This can be explained either by analytical errors or by adsorption phenomena occurring at the surface of the membranes.

Iodide ion $\left(0.05 \mathrm{mg}^{-} \mathrm{I}^{-} / \mathrm{L}\right)$ reacts with chlorine and bromine to form hypoiodious acid (HOI) (Equations 4-5). 


$$
\begin{aligned}
& \mathrm{HOCl}+\mathrm{I}^{-} \rightarrow \mathrm{HOI}+\mathrm{Cl}^{-} \\
& \mathrm{HOBr}+\mathrm{I}^{-} \rightarrow \mathrm{HOI}+\mathrm{Br}^{-}
\end{aligned}
$$

Hypoiodous acid is expected to react with organic matter to form iodinated DBPs, including I-THMs or I-HAAs. I-THMs, especially iodoform $\left(\mathrm{CHI}_{3}\right)$, were associated with a medicinal taste and odor in finished drinking water [35]. Although the formation of I-THMs is favored by chloramination [36,37], the occurrence of dichloroiodomethane $\left(\mathrm{CHCl}_{2} \mathrm{I}\right)$ and bromochloroiodomethane $(\mathrm{CHBrClI})$ was reported in U.S. chlorinated drinking waters exhibiting low levels of iodide ion $(7.3 \mu \mathrm{g} / \mathrm{L})$ [6]. In general, ITHMs formation has been associated with short chlorine contact times $[6,38]$. This observation is related to the further oxidation of $\mathrm{HOI}$ to iodate $\left(\mathrm{IO}_{3}{ }^{-}\right)$at longer chlorine contact times, thus decreasing its potential reactivity to form I-THMs [39]. For both sampling campaigns, low concentrations of dibromoiodomethane $\left(\mathrm{CHBr}_{2} \mathrm{I}\right)$ and diiodobromomethane $\left(\mathrm{CHBrI}_{2}\right)$ were detected in all samples collected at the SWRO plant 2 after chlorination. Bromochloroiodomethane (CHBrClI) was also observed in the concentrate of each RO pass in July (Table S6, SI). $\mathrm{CHBr}_{2} \mathrm{I}$ and $\mathrm{CHBrI}_{2}$ were present in July in the permeate of the $2^{\text {nd }}$ pass $/ 1^{\text {st }}$ stage $(1.15$ and $0.60 \mu \mathrm{g} / \mathrm{L}$, respectively) and in the product water (0.92 and $0.58 \mu \mathrm{g} / \mathrm{L}$, respectively) (Figure 3 ). Their concentrations were usually slightly lower in July than in May, in accordance with results obtained for other DBPs. No sample was collected from the product water for the first sampling campaign in May, but $1.47 \mu \mathrm{g} / \mathrm{L}$ of $\mathrm{CHBr}_{2} \mathrm{I}$ was detected in the permeate water, and $\mathrm{CHBrI}_{2}$ was below detection limit. These two compounds have been found to be the most cytotoxic I-THMs after iodoform $\left(\mathrm{CHI}_{3}\right)$ [6]. No $\mathrm{CHI}_{3}$ was detected in the collected samples, competition between bromine and iodine for incorporation into the THMs shifting the product distribution from $\mathrm{CHI}_{3}$ to mixed species (e.g., $\mathrm{CHBr}_{2} \mathrm{I}$ and $\mathrm{CHBrI}_{2}$ ) [36]. 


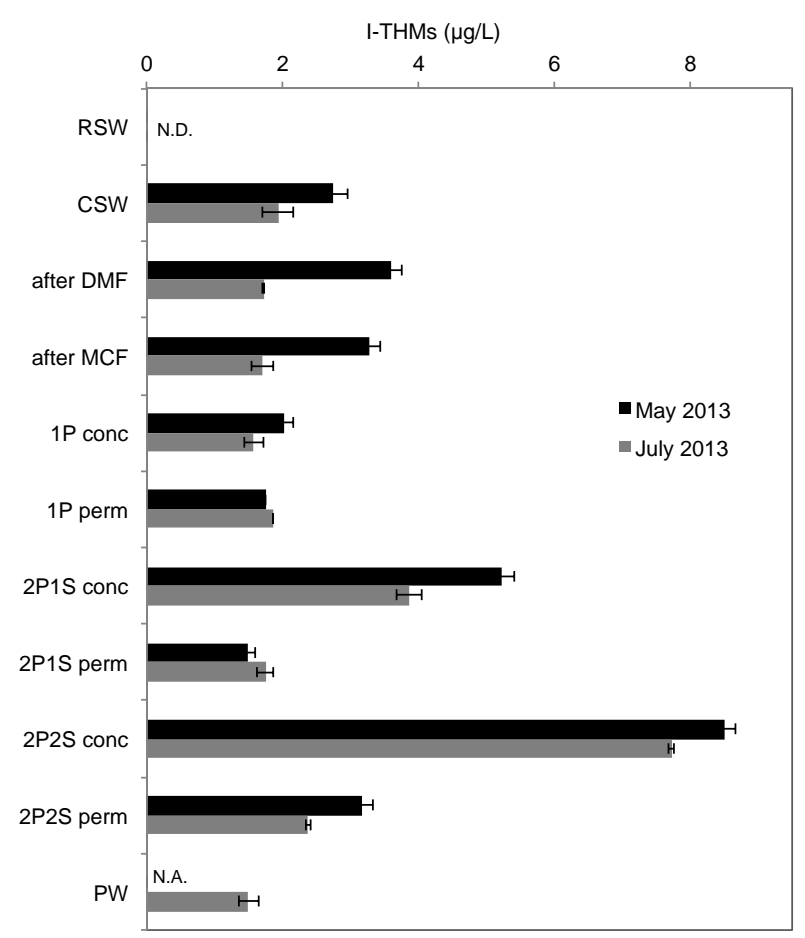

Figure 3. Concentrations of I-THMs in SWRO plant 2. RSW: raw seawater, CSW: chlorinated seawater, DMF: dual media filters, MCF: micron cartridge filters, $1 \mathrm{P} / 2 \mathrm{P}: 1^{\text {st }}$ and $2^{\text {nd }}$ RO pass, $1 \mathrm{~S} / 2 \mathrm{~S}: 1^{\text {st }}$ and $2^{\text {nd }}$ RO stage, perm: permeate, conc: concentrate, PW: product water. Error bars represent the standard deviation between duplicate samples. N.A.: Not Applicable.

\subsection{DBP formation during chlorination of membranes and isolated deposits}

During the $1^{\text {st }}$ sampling campaign at SWRO plant 2 (May 2013), additional samples were collected during the chlorination period of the $1^{\text {st }}$ pass RO membrane. While no HAAs were observed in the permeate when SBS was used to quench residual chlorine before the membranes (Figure 2), $4.15 \mu \mathrm{g} / \mathrm{L}$ TBAA was detected in the $1^{\text {st }}$ pass permeate during chlorination (Figure 4 and Table S7, SI). Interestingly, DBAA was the dominant species in the feed water of the $1^{\text {st }}$ RO pass (accounting for $78 \%$ of HAA9), but no DBAA was observed in the permeate. A higher concentration of HAA9 $(10.09 \mu \mathrm{g} / \mathrm{L})$ was also observed in the $1^{\text {st }}$ pass concentrate when membranes were chlorinated as compared to the 
period of no chlorination $(6.19 \mu \mathrm{g} / \mathrm{L})$. I-THMs $\left(\mathrm{CHBr}_{2} \mathrm{I}\right.$ and $\left.\mathrm{CHBrI}_{2}\right)$ followed the same trend, their concentration was slightly higher in the permeate during chlorination than in the absence of residual chlorine (2.84 and $1.74 \mu \mathrm{g} / \mathrm{L}$, respectively). An opposite effect was observed for THMs and HANs (i.e., lower concentrations) in the permeate and the concentrate in the absence of SBS injection. Chlorine was not able to prevent biofouling inside CTA RO modules (results not shown). Hence, HAA occurrence in the permeate could be attributed to the direct chlorination of organic material accumulated at the surface of membranes. Moreover, it was demonstrated that increased negative surface charge caused by fouling could expand the molecular weight cut-off of a RO membrane due to membrane swelling, thus resulting in lower rejection and increased diffusion of organic solutes [34]. Fouling of RO membranes also increases the adsorption of hydrophobic non-ionic solutes such as THMs in the membrane and fouling layer thus resulting in a lower rejection [34]. Our results would indicate that chlorination of the CTA membrane and modification of the fouling layer enhance these effects, i.e. lower rejection of DBPs, more diffusion of HAAs, and adsorption of THMs and HANs.

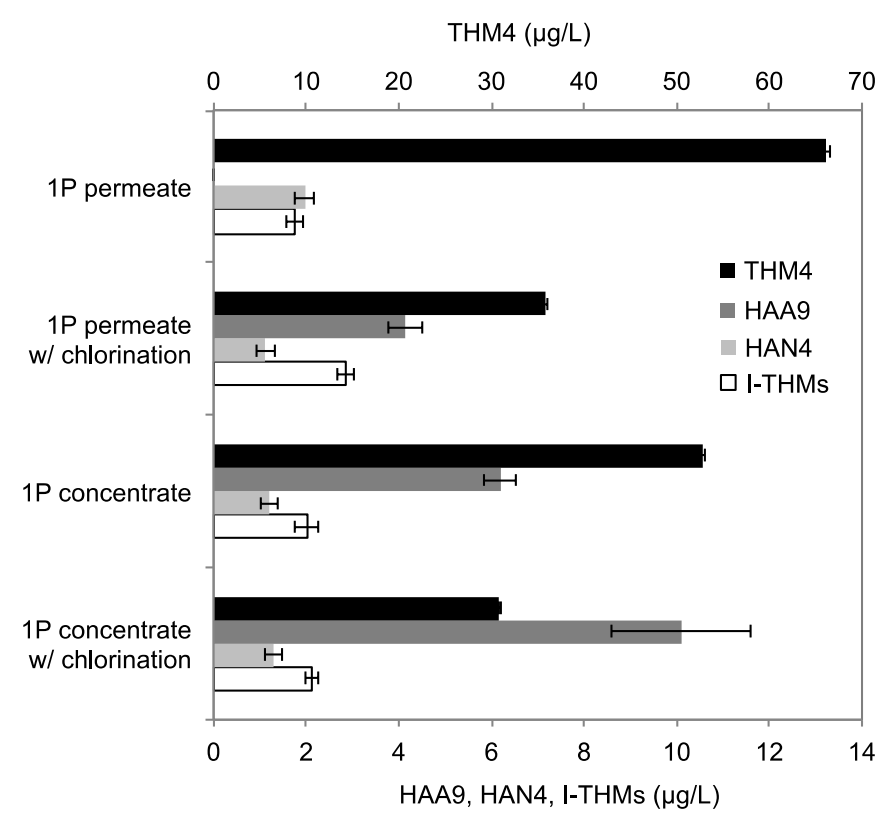

Figure 4. Concentrations of THM4, HAA9, HAN4 and I-THMs in SWRO plant 2 during dechlorination $\left(1.5-2.5 \mathrm{mg} / \mathrm{L}\right.$ of SBS) and chlorination period $\left(0.7-1 \mathrm{mg} / \mathrm{L}\right.$ as $\mathrm{Cl}_{2}$, for $1 \mathrm{~h}$ every $\left.8 \mathrm{~h}\right)$ of the $\mathrm{RO}$ 
membrane. Error bars represent the standard deviation between duplicate samples.

In order to characterize and test the chlorine reactivity of the fouling layer, organic matter accumulated at the surface of a CTA membrane module was isolated. Solid deposits were recovered after freeze-drying with or without dialysis purification. The increase in $\mathrm{C}, \mathrm{H}$, and $\mathrm{N}$ relative abundances of the isolates (Table S9, SI) was an indicator of the efficiency of the dialysis steps to remove inorganic substances (iron and silicate). After the two successive dialysis steps (oxalic acid and hydrofluoric acid), the carbon content of the foulant material reached approximately $44 \%$, suggesting low inorganic residual [40]. A colloidal suspension was prepared from these organic materials (1 mg $\mathrm{C} / \mathrm{L})$ to determine their DBP formation potential by chlorination $\left(13 \mathrm{mg} / \mathrm{L}\right.$ as $\left.\mathrm{Cl}_{2}\right)$ for $24 \mathrm{~h}$ in synthetic seawater $\left(\mathrm{pH} 8.3, \mathrm{Br}^{-}=60 \mathrm{mg} / \mathrm{L}\right.$ as $\mathrm{Br}$ ). The chlorinated deposit (no dialysis) formed $206.86 \mu \mathrm{g} / \mathrm{mg}-\mathrm{C}$ of TBM, $37.52 \mu \mathrm{g} / \mathrm{mg}-\mathrm{C}$ of DBAN, $66.07 \mu \mathrm{g} / \mathrm{mg}-\mathrm{C}$ DBAA and $43.31 \mu \mathrm{g} / \mathrm{mg}-\mathrm{C}$ of TBAA (Figure S5, SI). These results indicate that the fouling layer of RO modules contains highly reactive organic matter exhibiting a high DBP formation potential. Similar concentrations were formed from the foulant material obtained after successive dialyses, indicating that iron and silicate do not play a significant role in the formation of DBPs. Hence, the regular chlorination of the fouled CTA membranes (1h every $8 \mathrm{~h})$ leads to DBP formation at the surface of the membrane and favors their diffusion through the membrane as described above (i.e., HAA results in the permeate, Figure 4). Membrane fouling and its impact on membrane properties is a complex process involving feed water composition, water chemistry, hydrodynamic conditions and membrane properties. Complementary studies are needed to understand why TBAA was the main species observed in the permeate during chlorination, although its molecular mass is the highest among HAA9.

\subsection{DBPs rejected with brine discharges}


From the average $29.21 \mu \mathrm{g} / \mathrm{L}$ and $281.68 \mu \mathrm{g} / \mathrm{L}$ of TBM detected in the $1^{\text {st }}$ pass and $2^{\text {nd }}$ pass $/ 2^{\text {nd }}$ stage brines, respectively, the estimated reject of TBM in seawater is $17 \mathrm{~kg} / \mathrm{d}$ (i.e., 6.2 Tones/year) at SWRO plant 2. Even if a major dilution effect occurs when brine water is rejected to the sea, and the high volatility of THMs makes them prone to evaporation (e.g., $21 \mathrm{~min}$ half-life for chloroform at $25^{\circ} \mathrm{C}$ in stirred reactor [41]), TBM has a significantly lower vapor pressure than chloroform (670 $\mathrm{Pa}$ and 20.8 $\mathrm{kPa}$ at $20^{\circ} \mathrm{C}$, respectively [42]), thus exhibiting a higher persistence potential. A $26 \mathrm{~h}$ half-life has been reported for TBM in seawater [43]. This potential persistence associated with favorable currents may explain the relatively high THM concentrations observed in the seawater close to the plant intakes, especially SWRO plant 2 (Figure 5), consisting mainly of TBM (9-25 $\mu \mathrm{g} / \mathrm{L})$. While low levels of TBM can be produced naturally by benthic and planktonic algae $(0.8-23 \mathrm{ng} / \mathrm{L}$ reported in various seas and oceans [14]), THMs were previously reported near MSF plants at levels up to $9.5 \mu \mathrm{g} / \mathrm{L}$ [11] and $90 \mu \mathrm{g} / \mathrm{L}$ [12]. Considering the higher boiling points of HAAs and HANs as compared to THMs (especially the brominated species, e.g., 150, 195 and $180{ }^{\circ} \mathrm{C}$ for TBM, DBAA and DBAN, respectively), the persistence of these compounds is expected to be even higher than that of THMs. However, a $14 \mathrm{~h}$ halflife was reported for DBAN in seawater, so its persistence might not be as high as the one of TBM (26 h half-life) [43]. 


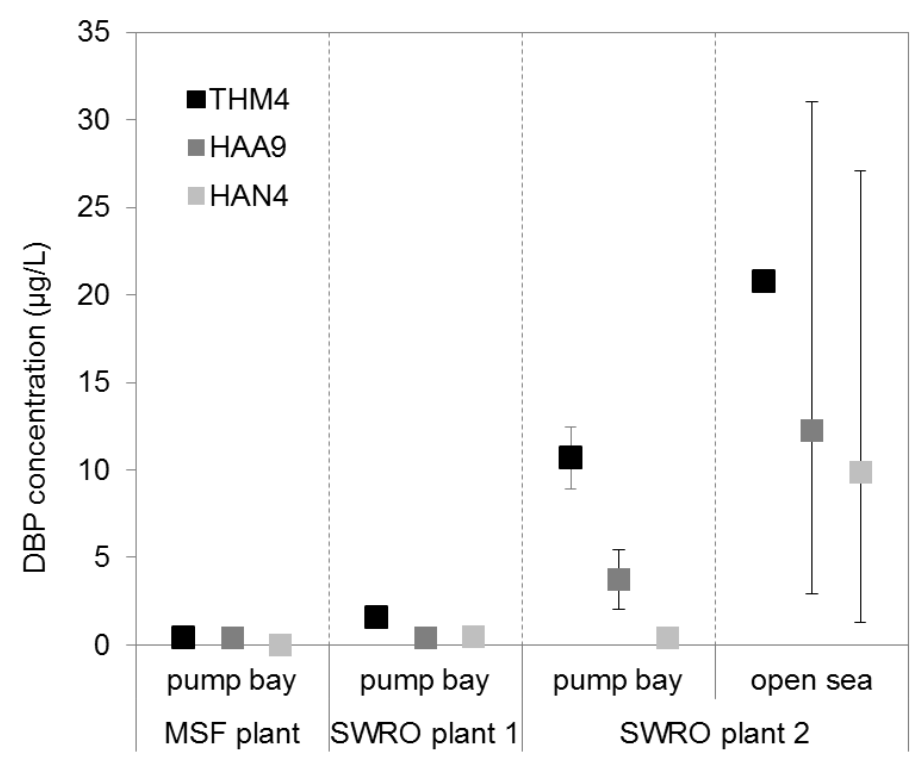

Figure 5. DBP occurrence in raw seawater of the monitored desalination plants. Squares represent mean values obtained for each plant. Mean values for SWRO plant 2 open sea sample were calculated based on three different locations and between the two sampling campaigns (May and July 2013). Error bars represent the highest and lowest value obtained from the two sampling campaigns.

Because most of DBPs are rejected through its venting system, rejects through the brine blowdown of the MSF plant were only $67 \mathrm{~g} / \mathrm{d}$ of THM4 and $64 \mathrm{~g} / \mathrm{d}$ of DBAN. In SWRO plant 1, the low concentrations of DBPs measured in the $1^{\text {st }}$ pass brine (Table S3, SI) led to an estimated reject of TBM of $52 \mathrm{~g} / \mathrm{h}(1.2 \mathrm{~kg} / \mathrm{d})$. The actual amount of TBM rejected in the brine would, however, be considerably lower because samples were collected during the chlorination period, which is only applied $3 \mathrm{~h}$ per day.

These low DBP contents in the brine of MSF plant and SWRO plant 1 may explain the lower concentrations observed in their pump bays $(0.81$ and $2.78 \mu \mathrm{g} / \mathrm{L}$ total DBPs, respectively) (Figure 5). DBP concentrations were higher in the seawater samples collected in the pump bay and on shore near SWRO plant 2. Concentrations of DBAA up to $24.84 \mu \mathrm{g} / \mathrm{L}$ were detected in May 2013 in the open seawater sample but were closer to $1.94 \pm 0.29 \mu \mathrm{g} / \mathrm{L}$ in the pump bay and in July 2013. TBAA was also detected in the open seawater sample $(5.26 \mu \mathrm{g} / \mathrm{L})$ and pump bay $(1.67 \mu \mathrm{g} / \mathrm{L})$. Most HANs were detected 
in the seawater sample collected in May 2013 and consisted mainly of DBAN with a concentration up to $26.81 \mu \mathrm{g} / \mathrm{L}$. Other locations and sampling times exhibited concentrations lower than $1 \mu \mathrm{g} / \mathrm{L}$ (data not shown). The concentrations of DBPs measured in the pump bay of SWRO plant 2 were lower than those detected in the open seawater, probably because it is located further away from the discharge point.

Several biotic (e.g., biodegradation) and abiotic (e.g., photolysis, hydrolysis, dilution, evaporation, adsorption) mechanisms contribute to the decomposition of DBPs in seawater [14]. Although most DBPs concentrations would be reduced within a few kilometers, their mutagenic character, their persistence and their bioaccumulation are a potential threat to sensitive species subject to chronic exposure in the vicinity of the point of discharge [44]. Nitrogenous, brominated and iodinated compounds are of particular concern because of their enhanced toxicity as compared to chlorinated byproducts [3].

\section{Conclusions and recommendations}

- These results suggest that there is low concern for DBP formation and discharge at desalination plants exhibiting a good seawater quality at the intake and using chlorine intermittently. Plants using continuous chlorination at the intake and showing higher DOC concentrations or presence of algal bloom may be facing a higher formation of DBPs, a portion of which can ultimately reach the product water in conjunction with substantial amounts discharged to the sea.

- Due to environmental and health issues raised by DBPs production and discharge, several alternative disinfectants have been considered, including monochloramine, copper sulfate, ozone and chlorine dioxide [10]. The latter is being considered the best alternative to chlorine since it forms less DBPs. 
- Increasing chlorine contact time is expected to reduce the concentration of HOI and thus the production of I-THMs, especially $\mathrm{CHI}_{3}$, which can be problematic due to their potential toxicity and taste and odor associated problems.

\section{Acknowledgments}

The authors thank NOMAC for providing access to desalination plants. Research reported in this publication was supported by the King Abdullah University of Science and Technology (KAUST). The authors would also like to thank Dr. Leo Gutierrez for his assistance and support.

\section{Supporting Information}

Description of the monitored DBPs, DBPs raw results tables, flow charts of desalination plants and additional figures.

\section{References}

[1] M.J. Plewa, E.D. Wagner, P. Jazwierska, S.D. Richardson, P.H. Chen, A.B. McKague, Halonitromethane drinking water disinfection byproducts: Chemical characterization and mammalian cell cytotoxicity and genotoxicity, Environ. Sci. Technol. 38 (2004) 62-68.

[2] M.G. Muellner, E.D. Wagner, K. Mccalla, S.D. Richardson, Y.-T. Woo, M.J. Plewa, Haloacetonitriles vs. regulated haloacetic acids: Are nitrogen-containing DBPs more toxic?, Environ. Sci. Technol. 41 (2007) 645-651.

[3] Plewa M J, Wagner E D, Muellner M G, Hsu K-M, Richardson S D, Comparative Mammalian Cell Toxicity of N-DBPs and C-DBPs, in: Disinfect. -Prod. Drink. Water, American Chemical Society, 2008: pp. 36-50. http://dx.doi.org/10.1021/bk-2008-0995.ch003 (accessed June 28, 2013).

[4] T. Bond, M.R. Templeton, N. Graham, Precursors of nitrogenous disinfection by-products in drinking water-A critical review and analysis, J. Hazard. Mater. 235-236 (2012) 1-16. doi:10.1016/j.jhazmat.2012.07.017.

[5] A. Dotson, P. Westerhoff, S.W. Krasner, Nitrogen enriched dissolved organic matter (DOM) isolates and their affinity to form emerging disinfection by-products, Water Sci. Technol. 60 (2009) 135-143.

[6] S.D. Richardson, F. Fasano, J.J. Ellington, F.G. Crumley, K.M. Buettner, J.J. Evans, et al., Occurrence and mammalian cell toxicity of iodinated disinfection byproducts in drinking water, Environ. Sci. Technol. 42 (2008) 8330-8338.

[7] S.D. Richardson, M.J. Plewa, E.D. Wagner, R. Schoeny, D.M. DeMarini, Occurrence, genotoxicity, and carcinogenicity of regulated and emerging disinfection by-products in drinking water: A review and roadmap for research, Mutat. Res. - Rev. Mutat. Res. 636 (2007) 178-242.

[8] US Environmental Protection Agency (USEPA), National Primary Drinking Water Regulations, 2009. http://www.epa.gov/safewater/consumer/pdf/mcl.pdf.

[9] R. Miri, A. Chouikhi, Ecotoxicological marine impacts from seawater desalination plants, Desalination. 182 (2005) 403-410. doi:10.1016/j.desal.2005.02.034. 
[10] S. Lattemann, T. Höpner, Environmental impact and impact assessment of seawater desalination, Desalination. 220 (2008) 1-15. doi:10.1016/j.desal.2007.03.009.

[11] T. Saeed, H. Khordagui, H. Al-Hashash, Contribution of power/desalination plants to the levels of halogenated volatile liquid hydrocarbons in the coastal areas of Kuwait, Desalination. 121 (1999) 49-63.

[12] M.Y. Ali, J.P. Riley, The distribution of halomethanes in the coastal waters of Kuwait, Mar. Pollut. Bull. 17 (1986) 409-414.

[13] H.A. Jenner, C.J.L. Taylor, M. van Donk, M. Khalanski, Chlorination by-products in chlorinated cooling water of some European coastal power stations, Mar. Environ. Res. 43 (1997) 279-293. doi:10.1016/S0141-1136(96)00091-8.

[14] E. Fogelqvist, M. Krysell, Naturally and anthropogenically produced bromoform in the Kattegatt, a semi-enclosed oceanic basin, J. Atmospheric Chem. 13 (1991) 315-324.

[15] M.E. Stewart, W.J. Blogoslawski, R.Y. Hsu, G.R. Helz, By-products of oxidative biocides: toxicity to oyster larvae, Mar. Pollut. Bull. 10 (1979) 166-169. doi:10.1016/0025-326X(79)904235.

[16] R. Kuhn, M. Pattard, Results of the harmful effects of water pollutants to green algae (scenedesmus subspicatus) in the cell mulitplication inhibition test, Water Res. 24 (1990) 31-38. doi:10.1016/0043-1354(90)90061-A.

[17] N.A. Latif, F.M. Al-Awadi, B.A. Colenutt, Trihalomethanes (THMs) formation in multi-stage flash (MSF) distillation plants, Desalination. 74 (1989) 205-226. doi:10.1016/00119164(89)85052-0.

[18] M.Y. Ali, J.P. Riley, The production of brominated methanes in desalination plants in Kuwait, Water Res. 23 (1989) 1099-1106.

[19] P.C. Mayankutty, A. Amin Nomani, T.S. Thankachan, Monitoring of organic compounds in feed and product water samples from MSF plants in the eastern coast of Saudi Arabia, Desalination. 74 (1989) 243-257. doi:10.1016/0011-9164(89)85054-4.

[20] A.G.I. Dalvi, R. Al-Rasheed, M.A. Javeed, Haloacetic acids (HAAs) formation in desalination processes from disinfectants, Desalination. 129 (2000) 261-271. doi:10.1016/S00119164(00)00066-7.

[21] A. Verliefde, N. Van Vliet, G. Amy, B. Van Der Bruggen, J.C. Van Dijk, A semi-quantitative method for prediction of the rejection of uncharged organic micropollutants with nanofiltration, Water Pr. Technol. 1 (2006).

[22] C. Bellona, J.E. Drewes, P. Xu, G. Amy, Factors affecting the rejection of organic solutes during $\mathrm{NF} / \mathrm{RO}$ treatment - A literature review, Water Res. 38 (2004) 2795-2809. doi:10.1016/j.watres.2004.03.034.

[23] Y. Magara, T. Aizawa, S. Kunikane, M. Itoh, M. Kohki, M. Kawasaki, et al., The behavior of inorganic constituents and disinfection by products in reverse osmosis water desalination process, 1996.

[24] K.O. Agenson, J.-I. Oh, T. Urase, Retention of a wide variety of organic pollutants by different nanofiltration/reverse osmosis membranes: Controlling parameters of process, J. Membr. Sci. 225 (2003) 91-103. doi:10.1016/j.memsci.2003.08.006.

[25] E. Agus, D.L. Sedlak, Formation and fate of chlorination by-products in reverse osmosis desalination systems, Water Res. 44 (2010) 1616-1626. doi:10.1016/j.watres.2009.11.015.

[26] K. Grasshoff, M. Ehrhardt, K. Kremling, L.G. Anderson, Methods of Seawater Analysis, Wiley, 1999. http://books.google.com.sa/books?id=ep1A02HN1MIC.

[27] S.W. Krasner, M.J. Sclimenti, Y.C. Guo, C.J. Hwang, P. Westerhoff, Development of DBP and nitrosamine formation potential tests for treated wastewater, reclaimed water, and drinking water, in: Proc 2004 AWWA Water Qual. Technol. Conf. Denver, AWWA, 2004.

[28] D.J. Munch, D.P. Hautman, EPA Method 551.1 Determination of Chlorination Disinfection Byproducts, Chlorinated Solvents, and Halogenated Pesticides/Herbicides in Drinking Water by 
Liquid-Liquid Extraction and Gas Chromatography with Electron-Capture Detection, Revision 1.0, United States Environmental Protection Agency, Cincinnati, OH, 1995.

[29] D.J. Munch, J.W. Munch, EPA Method 552.2 Determination of Haloacetic Acids and Dalapon in Drinking Water by Liquid-liquid Extraction, Derivatization and Gas Chromatography with Electron Capture Detection, Revision 1.0, United States Environmental Protection Agency, Cincinnati, OH, 1995.

[30] L. Heller-Grossman, J. Manka, B. Limoni-Relis, M. Rebhun, Formation and distribution of haloacetic acids, THM and TOX in chlorination of bromide-rich lake water, Water Res. 27 (1993) 1323-1331.

[31] World Health Organization, Guidelines for drinking-water quality, Volume 1, Recommendations, Geneva, 2008.

[32] D.A. Reckhow, A.L. MacNeill, T.L. Platt, A.L. MacNeill, J.N. McClellan, Formation and degradation of dichloroacetonitrile in drinking waters, J. Water Supply Res. Technol. - AQUA. 50 (2001) 1-13.

[33] Y. Kojima, Y. Kusakabe, S. Hatakeyama, Behavior of Trihalomethane in reverse osmosis desalination processes for seawater, Water Supply. 13 (1995) 309-313.

[34] P. Xu, J.E. Drewes, T.-U. Kim, C. Bellona, G. Amy, Effect of membrane fouling on transport of organic contaminants in NF/RO membrane applications, J. Membr. Sci. 279 (2006) 165-175. doi:10.1016/j.memsci.2005.12.001.

[35] R.C. Hansson, M.J. Henderson, P. Jack, R.D. Taylor, Iodoform taste complaints in chloramination, Water Res. 21 (1987) 1265-1271.

[36] Y. Bichsel, U. Von Gunten, Formation of iodo-trihalomethanes during disinfection and oxidation of iodide-containing waters, Environ. Sci. Technol. 34 (2000) 2784-2791.

[37] G. Hua, D.A. Reckhow, Comparison of disinfection byproduct formation from chlorine and alternative disinfectants, Water Res. 41 (2007) 1667-1678. doi:10.1016/j.watres.2007.01.032.

[38] D.B. Jones, A. Saglam, A. Triger, H. Song, T. Karanfil, I-THM Formation and Speciation: Preformed Monochloramine versus Prechlorination Followed by Ammonia Addition, Environ. Sci. Technol. 45 (2011) 10429-10437. doi:10.1021/es202745t.

[39] J. Criquet, S. Allard, E. Salhi, C.A. Joll, A. Heitz, U. Von Gunten, Iodate and iodo-trihalomethane formation during chlorination of iodide-containing waters: Role of bromide, Environ. Sci. Technol. 46 (2012) 7350-7357.

[40] J. Leenheer, Systematic Approaches to Comprehensive Analyses of Natural Organic Matter, Ann. Environ. Sci. 3 (2009). http://iris.lib.neu.edu/aes/vol3/iss1/13.

[41] W.L. Dilling, N.B. Tefertiller, G.J. Kallos, Evaporation rates and reactivities of methylene chloride, chloroform, 1,1,1-trichloroethane, trichloroethylene, tetrachloroethylene, and other chlorinated compounds in dilute aqueous solutions, Environ. Sci. Technol. 9 (1975) 833-838. doi:10.1021/es60107a008.

[42] Linstrom, P.J.; Mallard, W.G. (eds.) NIST Chemistry WebBook, NIST Standard Reference Database Number 69. National Institute of Standards and Technology, Gaithersburg MD. http://webbook.nist.gov (accessed 2014-06-03), n.d.

[43] C.J.L. Taylor, The effects of biological fouling control at coastal and estuarine power stations, Mar. Pollut. Bull. 53 (2006) 30-48. doi:10.1016/j.marpolbul.2006.01.004.

[44] A. Abarnou, L. Miossec, Chlorinated waters discharged to the marine environment chemistry and environmental impact. An overview, Sci. Total Environ. 126 (1992) 173-197. doi:10.1016/00489697(92)90490-J. 